EETP Vol. 16, 2021, №. 4(62)

ISSN 1896-2327 / e-ISSN 2353-7787

DOI: $10.35765 /$ eetp.2021.1662.02

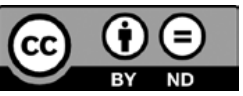

Nadesłano: 7.09.2021

Zaakceptowano: 18.10.2021

Sugerowane cytowanie: Kuźnik M. (2021). Kulturowe wzorce osobowe a wychowanie wspótczesnego dziecka, „Edukacja Elementarna w Teorii i Praktyce”, vol. 16, nr 4(62), s. 27-40. DOI: 10.35765/eetp.2021.1662.02

\title{
Marta Kuźnik
}

\section{Kulturowe wzorce osobowe a wychowanie współczesnego dziecka}

\section{Cultural Personal Patterns and the Upbringing of a Modern Child}

\begin{tabular}{|c|c|}
\hline SŁOWA KLUCZE & ABSTRAKT \\
\hline $\begin{array}{r}\text { wzorce osobowe, } \\
\text { modele wychowania, } \\
\text { osobowość, } \\
\text { media, relacje } \\
\text { międzyludzkie, } \\
\text { nauczyciel, rodzina }\end{array}$ & $\begin{array}{l}\text { Tematyka wzorców osobowych jest niezmiernie ważna w obecnych } \\
\text { czasach przepełnionych wpływem różnych kultur czy kierunków } \\
\text { odziaływań, między innymi środków masowego przekazu, narzędzi } \\
\text { wirtualnych czy współczesnych „idoli”. A przecież odpowiednio do- } \\
\text { brane wzorce osobowe dostarczają dzieciom i młodzieży konkretnych } \\
\text { wartości do naśladowania, wybierają ogromny wpływ na ich wyob- } \\
\text { raźnię i psychikę. Mobilizują do pozytywnego działania i prawidło- } \\
\text { wego funkcjonowania w życiu społecznym. Ogromną rolę odgrywa } \\
\text { również osobowość każdego człowieka. Artykuł jest zatem próbą od- } \\
\text { powiedzi na pytanie, czy we współczesnych czasach istnieją wzorce } \\
\text { osobowe, które zyskują zainteresowanie dzieci i młodzieży. Wyjaśnia } \\
\text { specyfikę wzoru osobowego na tle pojęć pokrewnych. Opisuje rolę } \\
\text { wzorów osobowych na różnych etapach rozwoju człowieka oraz mo- } \\
\text { dele wychowania obecne we współczesnej psychologii. }\end{array}$ \\
\hline
\end{tabular}




\section{KEYWORDS ABSTRACT}

personal The subject of personal role models is extremely important in today's patterns, models times filled with the influence of various cultures or directions of inof upbringing, fluence, including mass media, virtual tools or contemporary „idols”. personality, media, And yet, properly selected personal role models provide children and interpersonal adolescents with specific values to follow, exerting a huge influence relations, teacher, on their imagination and psyche. They encourage young people for family. positive action and proper functioning in social life. The personality of each person also plays an important role. Therefore, the article is an attempt to answer the question whether in modern times there are personal patterns that are interesting to children and youth. Also, the text explains the specificity of a personal pattern against the background of related concepts. Moreover, it describes the role of personal models at various stages of human development and models of education present in modern psychology.

\section{Wprowadzenie}

Nasze życie to sztuka wyborów. Każdego dnia podejmujemy dziesiątki decyzji mających mniejszy lub większy wpływ na nasze życie. Dotyczy to również dzieci i młodzieży. Osobowość każdego człowieka - chodź tak różna odgrywa tu bardzo ważną rolę. W życiu codziennym staramy się być indywidualistami, często jednak zapominamy, że jesteśmy istotami społecznymi. Według Huberta Rohrachera osobowość wyraża aktualny sposób bycia jednostki, czyli wynik predyspozycji, które dotychczas ukazały się pod wpływem środowiska (Graczykowski, Trojan 2003: 268). Zgodnie z tą definicją, osobowość człowieka jest zbiorem postaw bardziej lub mniej świadomie przejętych ze środowiska.

Jednym z istotnych oddziaływań na człowieka, przede wszystkim w okresie dzieciństwa czy młodości, jest tendencja obejmująca wpływ wzorów osobowych. Jest to temat szczególnie ważny dla współczesnego społeczeństwa, ponieważ wpływ różnych kierunków działań na młode pokolenie jest ogromny.

\section{Wzór osobowy a pojęcia pokrewne}

Problematyka oraz analizowanie wzorów osobowych i ich znaczenia w rozwoju poszczególnej jednostki wymaga dokonania ustaleń terminologicznych. Jest również od dawna obszarem zainteresowań wielu badaczy. Maria Ossowska (Ossowska 1992: 11) uważa, że pojęciem pokrewnym wzoru osobowego jest stereotyp, natomiast nie stanowi on, tak jak wzór, przedmiotu aspiracji jednostkowych i społecznych. Wprawdzie 
interakcje społeczne regulowane są przez istnienie zarówno stereotypów, jak i wzorów, lecz tylko te drugie wpływają modelująco na funkcjonowanie jednostki.

Encyklopedyczna definicja wzoru osobowego wskazuje na „wyobrażenie zespołu cech, do których posiadania aspiruje członek zbiorowości, chcąc być w zgodzie z postulowanym lub faktycznie w niej panującym systemem wartości, np. wzór osobowy rycerza, ziemianina, kupca, gentlemana, artysty, żołnierza, rewolucjonisty, uczonego" (https://encyklopedia.pwn.pl/haslo/wzor-osobowy;3999283.html [dostęp: 29.08.2021]). Takie ujęcie sugeruje, że wzór osobowy dotyczy pożądanych społecznie atrybutów jednostki. Zdecydowanie wyróżnia się spośród innych. Maria Ossowska (1992: 15-37), pisząc rozprawę na temat wzoru demokraty, przedstawiła trzynaście cech wzoru, który oddziałuje na człowieka żyjącego w ustroju demokratycznym, stwarzającym warunki do rozwoju indywidualnych możliwości jednostki. Wzór osobowy posiada, według niej, następujące atrybuty: 1) aspiracje perfekcjonistyczne - dążenie do doskonalenia życia zbiorowego i siebie, co wymaga umiejętności dokonywania właściwych wyborów zgodnie z ustaloną hierarchią wartości; 2) otwartość umysłu związana z umiejętnością przyznania się do błędu; 3) dyscyplina wewnętrzna umożliwiająca długotrwały wysiłek w imię wyższego dobra; 4) tolerancja rozumiana jako umiejętność szanowania potrzeb i opinii, których jednostka nie podziela; 5) aktywność - czynności „ulepszające”, faktyczne realizowanie aspiracji perfekcjonistycznych; 6) odwaga cywilna ujawniająca się w postaci głoszenia swoich przekonań pomimo zagrożenia i w imię wartości osobistych lub społecznych; 7) uczciwość intelektualna, czyli poszukiwanie prawdy; 8) krytycyzm - orientacja w różnych stanowiskach i poszukiwanie uzasadnień; 9) odpowiedzialność za słowo - dotrzymywanie umów i obietnic; 10) uspołecznienie - wszystkie kwalifikacje, które przyczyniają się do zgodnego współżycia, obejmujące między innymi: a) zainteresowanie zagadnieniami społecznymi, b) przezwyciężanie egocentryzmu, c) zorganizowaną i planowaną ofiarność dla realizowania celów zbiorowych, d) umiejętności współdziałania; 11) postawa fair play wobec przeciwnika; 12) wrażliwość estetyczna; 13) poczucie humoru (Bakiera, Harwas-Napierała 2016: 24). Wyróżnione przez autorkę cechy wzoru osobowego wskazują, że jest nim osoba o nieprzeciętnych właściwościach, osoba ceniona, która pozytywnie kształtuje życie społeczne.

Kategorią nadrzędną wobec wszystkich omawianych pojęć związanych z wzorcami osobowymi jest przede wszystkim osoba znaczaca. Termin ten wprowadził Harry Stack Sullivan na określenie osoby, której opinie mają szczególne znaczenie w kształtowaniu samowiedzy oraz osobowości (Siuta 2005: 12). Oddziaływanie osoby znaczącej zostawia szczególny ślad w strukturach psychicznych oraz zachowaniu jednostki, ma również fundamentalne znaczenie dla przebiegu rozwoju psychospołecznego, zarówno w dzieciństwie, adolescencji, jak i w dorosłości. Z tego względu można uznać, że jest to osoba ważna, przyczyniająca się do zmian rozwojowych innej 
osoby lub innych osób. Typowy przebieg rozwoju jednostki wiąże się z oddziaływaniem takich osób znaczących jak rodzice, nauczyciele, przyjaciele.

We wczesnym dzieciństwie osobami znaczącymi są przede wszystkim rodzice. Rozpoczęcie przez dziecko edukacji przedszkolnej, a następnie szkolnej, oznacza włączenie również nauczycieli w krąg osób znaczących. W adolescencji natomiast zdecydowanie wzrasta znaczenie rówieśników, co oznacza, że znaczącą staje się osoba wybrana, a nie tylko taka, z którą interakcje przebiegają bez intencjonalnego wyboru. W dorosłości osobami znaczącymi w rozwoju jednostki mogą być członkowie rodziny, przełożeni w pracy i współpracownicy. Osoba staje się znacząca wówczas, gdy istotnie kształtuje rozwój poszczególnej jednostki. Wszelakie interakcje kształtują osobowość, samowiedzę i tożsamość (Bakiera, Harwas-Napierała 2016: 20).

Kolejny termin związany z wzorcami osobowymi to model, który stosowany jest w odniesieniu do osoby mającej właściwości wzbudzania zachowań naśladowczych u obserwującej ją jednostki (Harwas-Napierała 2010: 7). Podkreśla się, że zachowanie demonstrowane przez model stanowi przedmiot społecznego uczenia się (Bąbel, Suchowierska, Ostaszewski 2014). Wśród cech modela, które sprzyjają odwzorowywaniu jego zachowań, wymienia się przede wszystkim kompetencję, wysoką pozycję społeczną, prestiż, autorytet, czynny udział w wychowaniu czy pozytywne następstwa zachowania się modela (Przetacznik-Gierowska, Włodarski 1994: 22).

Modelem najczęściej jest osoba, z którą obserwatora łączą silne więzi emocjonalne. W dzieciństwie są to więc przede wszystkim rodzice i inni opiekunowie. Na zachowanie młodzieży w większym stopniu oddziałują rówieśnicy. Urie Bronfenbrenner (1970b) uważa, że największe znaczenie w środowisku szkolnym mają nie tyle kompetencje nauczycieli czy programy nauczania, ile cechy rówieśników uczęszczających do tej samej szkoły. Podobny akcent stawiają Jeffrey S. Turner i Donald B. Helms (1999: 363), uznając, że grupa rówieśnicza staje się krytycznym czynnikiem socjalizacji dorastających. Rówieśnicy dostarczają interesujących modeli w procesie kształtowania się tożsamości, stanowią ponadto ważne źródło wsparcia i poczucia bezpieczeństwa.

Kolejne bardzo ważne pojęcie związane z wzorcami osobowymi to autorytet. Łacińskie znaczenie terminu (Kumaniecki 1999) wskazuje na powagę moralną, znaczenie, prestiż osoby, grupy lub organizacji, które budzą uznanie, wywierają wpływ na innych. W słowniku łacińsko-polskim występują trzy znaczenia autorytetu (Plezia 1974: 28): 1) prawo własności, powaga prawa, moc prawa, przepis prawa, poręczenie; 2) powaga, oficjalna opinia lub postanowienie senatu rzymskiego w jakiejś sprawie, dostojeństwo, moc bogów; 3) poważanie, szacunek, doniosłość, wpływ, uznanie, jakim ktoś cieszy się u ludzi. Władysław Kopaliński (2007: 28) odnosi pojęcie autorytetu do takich właściwości jak prestiż, powaga, wpływ, znaczenie, mir, które dotyczą zarówno człowieka, jak i instytucji. Stanisław Kowalik (2006), przywołując koncepcję heroizmu Thomasa Carlyle’a, zwraca uwagę, że dzieje dużych zbiorowości ludzkich 
kształtowane są przez autorytet Wielkiego Człowieka, którym jest postać wybitna, przewyższająca innych swoją inteligencją, odwagą i oryginalnością poglądów na życie (Bakiera, Harwas-Napierała 2016: 28).

W literaturze przedmiotu możemy odnaleźć również inne pojęcia, zbliżone do określenia wzoru osobowego. Lider (z ang. leader) to osoba przewodząca, która stoi na czele grupy. Wyróżnia go zdolność wywierania wpływu na innych członków grupy, przy czym jest to wpływ większy niż wywierają pozostali członkowie (Siuta: 2005). Jego działania polegają na organizowaniu życia grupowego, dbałości o spójność grupy pomimo istniejących różnic oraz wzajemny szacunek jej członków. Jego przywództwo (ang. leadership) polega na inspirowaniu i motywowaniu członków grupy do wysiłku w imię wspólnych celów oraz osiąganiu celów przy wsparciu ze strony innych osób (Covey: 2007; Leigh i Maynard: 1999). Dave Ulrich (1997: 220) uważa, że przywódca musi być wiarygodny, aby zdobyć zaufanie i zaangażowanie tych, którym przewodzi.

Mentor współcześnie termin ten stosowany jest na określenie mistrza, zaufanego nauczyciela, przewodnika i doradcy (Dohm i Cummings: 149153). Allison N. Ponce, Michelle K. Williams i George J. Allen (2005: 1162) nazywają mentora „menedżerem przyszłych pokoleń" z racji roli, jaką pełni on w kształtowaniu postaw młodszego pokolenia. Przyjęcie roli mentora oznacza zmianę pozycji w procesie socjalizacji - od bycia socjalizowanym do socjalizowania kogoś, od naśladowania zachowań dorosłych do modelowania ról społecznych. Cechują go takie atrybuty, jak umiejętność wchodzenia w relację interpersonalną i utrzymywania jej, wysoki poziom samoświadomości, umiejętności komunikacyjne, empatia, wrażliwość, altruizm (Guptan 2006). Uznaje się, że mentor jest wzorem do naśladowania (Gębska 2013: 2436) lub mistrzem, którego postawy stanowią wzorzec postępowania (Bąkiewicz 2013: 3743).

Tutor jest opiekunem, który dostosowuje metody pracy do możliwości ucznia. Jak zaznacza Zbigniew Pełczyński, który jako pierwszy tutor polskiego pochodzenia w historii Oksfordu w ciągu swojej oksfordzkiej kariery odbył ponad 1200 godzin tutoringu, celem aktywności tutora jest intelektualny rozwój ucznia. Tutor określa temat $\mathrm{w}$ formie problemu do rozwiązania, daje sugestie dotyczące literatury, a następnie dokonuje interpretacji tematu i dostosowuje go do osobowości i zdolności swojego ucznia. Jego zadaniem zaś jest znalezienie własnej perspektywy problemu oraz przedstawienie swojego punktu widzenia w jasny i interesujący sposób. Nadrzędnym celem tutoringu jest kształcenie kreatywnego myślenia i otwartości na innowacje. 


\section{Rola wzorów osobowych na różnych etapach rozwoju człowieka}

Oddziaływanie różnych wzorów osobowych następuje w całym ludzkim życiu, jednak ich siła i rodzaj mają szczególne znaczenie w fazach rozwoju przed dorosłością, w których następuje rozwój podstawowych cech osobowości, a przede wszystkim kształtuje się tożsamość jednostki. Zwraca się uwagę, że jednym z podstawowych zadań wychowania jest wspieranie młodych ludzi w rozwijaniu osobowości, poszukiwaniu własnej tożsamości oraz budowaniu systemu wartości, którym będą się w życiu kierować. Do osiągnięcia tych celów młodym ludziom potrzebne są autorytety i wzory osobowe (Spychalska 2012: 85). Jak już wcześniej wspomniano, do okresu dorastania osobami znaczącymi dla dziecka są przede wszystkim rodzice. Ich znaczenie dla przebiegu rozwoju psychicznego dziecka dopełniają inni członkowie rodziny, z którymi ma ono kontakt (rodzeństwo, dziadkowie), a także nauczyciele, opiekunowie, rówieśnicy. Nie wszystkie osoby w równym stopniu oddziałują jako wzory osobowe. Wpływ na dokonujące się zmiany rozwojowe wywierają w głównej mierze osoby, które mają częsty kontakt z dzieckiem i z którymi dziecko łączy bliska więź. Wraz z rozpoczęciem nauki przedszkolnej i szkolnej ważnymi wzorami osobowymi stają się nauczyciele.

Kontakty dziecka z nauczycielami otwierają je na oddziaływanie innych autorytetów. Ponad pół wieku temu Stanisław Gerstmann (1961: 1417) podkreślał, że autorytet nauczyciela opiera się na takich jego cechach jak rzetelna wiedza, zaufanie intelektualne ucznia, czyli wiara w prawdziwość i słuszność słów nauczyciela, mądrość życiowa, znajomość psychiki dziecięcej, szacunek oraz pozytywny uczuciowo stosunek do ucznia. Badania Emilii Badury (1981: 119) nad uwarunkowaniami autorytetu nauczyciela wskazują, że istotne znaczenie ma stopień zaspokojenia potrzeb ucznia, podobieństwo postaw oraz konstruktywne stosunki między nauczycielem a uczniem. Oddziaływanie nauczycieli jako wzorów osobowych w pewnym stopniu jest odzwierciedleniem modelowania, jakiemu ulegali we wcześniejszych fazach rozwojowych. Zwraca na to uwagę Stanisław Dobrowolski (1948: 73), pisząc, że pierwszą praktyką, jaką każdy nauczyciel przechodzi już w latach dziecięcych i młodzieńczych, jest jego pobyt w szkole w charakterze wychowanka. Autor ponadto przedstawił pożądane cechy nauczyciela, które można uznać za atrybuty pozytywnego wzorca wychowawcy. Należą do nich: właściwości emocjonalne (bliski stosunek do człowieka), umysłowe (jasność umysłu, organizacyjność, wyobraźnia) i wolicjonalne (odpowiedzialność, obowiązkowość, konsekwencja w postępowaniu). Nauczyciel stanowi ważny dla dziecka model zachowań i norm postępowania, szczególnie w okresie nauczania wczesnoszkolnego. Specyfika i odrębność pracy nauczyciela wyraża się w szczególnych możliwościach doświadczenia samego siebie. Zawsze istotnym zagadnieniem będzie to, kim jest nauczyciel dla ucznia, czy jest osobowością szczególną, wybitnie oddziałującą, czy 
tylko osobą w różnych sytuacjach edukacyjnych. Przez swoje zachowanie uczy jak postępować z ludźmi, wskazuje na cechy charakteru, które są niezbędne do właściwego funkcjonowania w społeczeństwie. Wychowawca to wzór dla dzieci, dlatego tak ważne - oprócz kompetencji, które mają wpływ na prawidłowy przebieg jego pracy - są jego cechy osobowości, których nie można się nauczyć.

Ważne jest, aby szczególnie nauczyciela edukacji przedszkolnej i wczesnoszkolnej cechowała otwartość na dialog. Wtedy jest tym, który korzysta z demokratycznego stylu wychowania, dzięki czemu umożliwia swoim wychowankom wspólne podejmowanie decyzji. Często odwołuje się do inicjatyw i pomysłów dzieci. Zachęca je do przedyskutowywania różnych tematów, argumentowania swoich stanowisk w danej sprawie. Tym samym uczy działania w grupie i wskazuje, jak ważny jest kompromis. W ten sposób staje się inicjatorem i doradcą, który towarzyszy i pomaga dzieciom w różnych momentach ich życia.

W okresie średniego i późnego dzieciństwa poza nauczycielskimi wzorami osobowymi występują również modele koleżeńskie. Sama obecność rówieśników może wywoływać efekty modelowania, czyli uczenia się zachowań, których wcześniej dziecko nie posiadało, efekty wywoływania czynności opanowanych wcześniej lub efekty zahamowania-odhamowania, gdy zauważy określone skutki działań rówieśnika (Bandura 1985: 2544). Współczesny świat zdecydowanie utrudnia zdobywanie przez dzieci i młodzież wartościowych wzorców osobowych. Jednym z takich czynników jest intensywny udział środków masowego przekazu. Media współcześnie starają się zawłaszczyć styl życia nastolatków i ukształtować ich gusta w taki sposób, by byli konsumentami treści i produktów. Szczególnie zagrożeni są młodzi ludzie, którzy budują poczucie swojej tożsamości zarówno indywidualnej, jak i grupowej na bazie przekazów medialnych. Tworzenie obrazu świata, obrazu siebie, kształtowanie światopoglądu, uczenie się relacji społecznych odbywa się dziś najczęściej właśnie za pośrednictwem narzędzi wirtualnych (Masłyk-Zawisza 2013: 34).

W natłoku informacji docierających do jednostki występuje wręcz syndrom informacyjnego śmietnika (Kwiatkowski 2013: 53), w którym jednostka nieustannie dokonuje selekcji. Nie oznacza to jednak, że zawsze wybiera informacje wartościowe z punktu widzenia jej rozwoju. Istotne wobec tego jest, na ile wśród kodowanych i analizowanych informacji występują te, które mają pozytywną wartość kreująca spójną, dojrzałą osobowość. Wzrastający udział środków masowego przekazu w procesie socjalizacji dzieci i młodzieży powoduje, że następuje przesunięcie socjalizacyjne (Kwieciński 1996). Polega ono na spadku znaczenia tradycyjnych instytucji socjalizacyjnych (rodzina, szkoła, Kościół) i przejmowaniu ich roli między innymi przez media, a także grupy rówieśnicze i szeroko rozumianą kulturę popularną. Podkreśla się, że jeżeli wpływ mediów i grupy odbywa się z pominięciem lub przy braku dostatecznego wpływu pozostałych środowisk socjalizacyjnych, przede wszystkim rodziny, zachodzi 
niebezpieczeństwo kształtowania niedojrzałej osobowości jednostki (Fudali 2008). Telewizja, Internet, gry komputerowe stają się kuszącą alternatywą wobec realnej, często bardzo trudnej dla dziecka, nastolatka czy dorosłego rzeczywistości.

\section{Przykłady kulturowych wzorów osobowych}

Zagadnienia dotyczące kształtowania i wychowania współczesnego dziecka stają się szczególnie istotną kwestią w czasach globalizacji kultury, kiedy to mamy do czynienia z ciągłą interakcją różnych kultur czy wzajemną wymianą treści kulturowych. „Większość przekazów jest jednokierunkowa, z wyraźnym wyróżnieniem centrów i peryferii. Centra inicjują przekaz kulturowy, peryferia natomiast przejmują i adaptują. W konsekwencji dochodzi do globalnej homogenizacji, nasycenia kulturowego peryferii, często również do deformacji kulturowych, hybrydyzacji kultur (Muszyńska: 2005: 114).

Ralph Linton twierdził, że każda kultura kreuje określone wzorce osobowe, a więc standardy postępowania, które narzuca jednostce w zależności od miejsca, jakie zajmuje ona w poszczególnych systemach. Wzorce różnicują się w zależności od płci, wieku, pozycji w rodzinie czy w społeczeństwie.

Tabela 2. Wzorce młodych od średniowiecza do naszych czasów

\begin{tabular}{|c|c|c|c|c|}
\hline Średniowiecze & $\begin{array}{l}\text { Renesans - } \\
\text { - XVIII w. }\end{array}$ & XIX w. - lata 50. & $1960-1980$ & Koniec XX w. \\
\hline $\begin{array}{c}\text { Okres } \\
\text { bohaterów }\end{array}$ & $>\begin{array}{c}\text { Okres } \\
\text { mistrzów }\end{array}$ & $\begin{array}{c}\text { Okres } \\
\text { przewodników }\end{array}$ & $>\begin{array}{c}\text { Okres } \\
\text { idoli }\end{array}$ & $\begin{array}{c}\text { Zmierzch } \\
\text { bogów }\end{array}$ \\
\hline $\begin{array}{l}\text { Identyfikacja } \\
\text { z rycerstwem }\end{array}$ & Uczeni & Wielcy wodzowie & $\begin{array}{c}\text { Młodzieżowe } \\
\text { gwiazdy }\end{array}$ & $\begin{array}{c}\text { Grupa } \\
\text { (jako substytut ojca) }\end{array}$ \\
\hline Zdobywcy & $\begin{array}{l}\text { Wielcy żeglarze } \\
\text { i podróżnicy }\end{array}$ & $\begin{array}{l}\text { Bojownicy } \\
\text { o wolność }\end{array}$ & $\begin{array}{c}\text { Szefowie } \\
\text { band }\end{array}$ & $\begin{array}{c}\text { Grupa } \\
\text { rówieśników }\end{array}$ \\
\hline $\begin{array}{l}\text { Rytuały } \\
\text { Inicjacyjne }\end{array}$ & Przyuczanie & $\begin{array}{c}\text { Koniec } \\
\text { przyuczania }\end{array}$ & $\begin{array}{l}\text { Ani Boga, } \\
\text { ani mistrza }\end{array}$ & $\begin{array}{c}\text { Koniec } \\
\text { ideologii }\end{array}$ \\
\hline $\begin{array}{c}\text { Władza } \\
\text { i mistycyzm }\end{array}$ & $\begin{array}{c}\text { Przeciwstawienie } \\
\text { władzy } \\
\text { i świadomości }\end{array}$ & $\begin{array}{c}\text { Koniec republiki } \\
\text { profesorów }\end{array}$ & Powrót narcyzmu & $\begin{array}{c}\text { Kult } \\
\text { zgromadzenia }\end{array}$ \\
\hline $\begin{array}{l}\text { Uczestnicy } \\
\text { krucjat, } \\
\text { męczennicy }\end{array}$ & Geniusze & Rewolucjoniści & $\begin{array}{c}\text { Esteci } \\
\text { i fałszywi prorocy }\end{array}$ & $\begin{array}{l}\text { Stowarzyszenia } \\
\text { humanitarne, } \\
\text { wielkie sprawy }\end{array}$ \\
\hline
\end{tabular}

Źródło: Uczyć się od idola. O istotnym źródle wiedzy potocznej uczniów, [w:] Wychowanie, red. M. Dudzikowa, M. Czerepaniak-Walczak, (2007). Gdańsk: GWP. 
Na przestrzeni dziejów pojęcie wzorca osobowego ulegało przekształceniu. W starożytnej Sparcie autorytetem obdarzano człowieka, który zasługiwał na sławę dzięki sprawności fizycznej, który na polu bitwy bohatersko stawiał czoła wrogowi. Natomiast w Atenach autorytetem mógł być człowiek mądry o szerokich horyzontach. W średniowieczu z kolei autorytetem był człowiek religijny i pobożny. Jak widać, wzorce proponowane młodzieży ewoluowały na przestrzeni wieków od bohaterów, kiedy pochodziły od rycerstwa, poprzez okres mistrzów, za których uważano wielkich uczonych, do epoki przewodników, którzy potrafili głoszonymi przez siebie ideami porwać rzesze ludzi. $Z$ historycznego punktu widzenia można również zauważyć tendencję do nasilenia oddziaływania wzorów męskich. Wzory osobowe w większym stopniu kształtowały zachowanie mężczyzn (wzór mędrca, wojownika, gentlemana). Wzory kobiece były znacznie mniej urozmaicone i odnosiły się w głównej mierze do ról rodzinnych.

Lata sześćdziesiąte XX wieku przyniosły ze sobą schyłek wielkich ideologii i wartości. Wszystkie dotychczasowe propozycje kreowania tożsamości okazały się niestałe, płynne, zabrakło im głębszego sensu. Wydaje się, że tendencja ta stała się dla współczesnego Europejczyka możliwością swoistego wyboru, ponieważ można siebie realizować na dowolne sposoby, nie ma narzucanych form, do których należy się bezwzględnie dostosować, z drugiej strony brak nam punktu odniesienia, wzoru osobowego, który jest ważny dla formułowania osobowości czy tożsamości młodego człowieka.

Współcześnie coraz trudniej o autorytety, gdyż świat społeczny jest postrzegany jako zmienny i wielowymiarowy. W tym zmiennym świecie rozchwianie funkcjonujących przez wieki systemów wartości, „migotanie znaczeń” wywoływane przez ekspansywnie rozwijające się i wszechobecne media, świat mody i reklamy, gdzie Internet w skali globalnej przekazuje ogrom informacji - zachodzi destabilizacja życia jednostek, grup społecznych, całych zbiorowości (Szymański: 2014: 82). Brak stabilnych wzorów postępowania wywołuje chaos w procesie budowania własnej tożsamości.

Jako Europejczycy mamy do wyboru innowacyjne, nowe style życia wobec tradycyjnych wartości reprezentowanych przez „dawną Europę”, a więc tzw. kanon tradycyjnych wartości kulturowych - w sferze wartości osobistych: życie, wolność i godność; w sferze wartości wspólnotowych: rodzina, wspólnota i religia, w sferze wartości absolutnych: prawda, dobro i piękno oraz Bóg. Tak zwane „nowe” jest wersją kultury globalnej, która oferuje ujednolicone wzory kulturowe, zunifikowany styl życia. Powstaje kategoria "globalnego nastolatka”, którego tożsamość jest w znacznie mniejszym stopniu kształtowana przez wartości narodowe i państwowe, w znacznie większym przez kulturę popularną oraz ideologię konsumpcji.

W społeczeństwach cywilizacji zachodnioeuropejskiej dominują tendencje indywidualistyczne, stanowiąc system norm i wartości determinujących możliwości adaptacyjne jednostek. Człowiek traktowany jest jako podmiot autonomiczny, 
samostanowiący o sobie i wyodrębniony ze środowiska społecznego, a indywidualizm postrzega się jako kulturową orientację normatywną (Nikitorowicz 2009: 371).

Cała historia cywilizacji może być zasadnie ujęta jako historia wzorów, ideałów i systemów aksjologicznych potraktowanych jako podstawa wydarzeń, tendencji i mód. To formy wartościowania warunkują bowiem dokonujące się wydarzenia. Ponadto wzory wystawiają danemu społeczeństwu moralne świadectwo, ujawniając naczelne wartości żywione przez jego członków. Wzór osobowy jest jakby emblematem społeczeństwa - to postać wzoru skupia jego dominujące tendencje i informuje, w czym ludzie upatrują naczelne dobra życiowe. Społeczeństwo stawiające na piedestale wzór rycerza różni się istotnie od tego, które za wzór ma kupca, i w nieco mniejszym stopniu od tego, które obiera wzór gentlemana (MacIntyre1996: 146).

\section{Cztery modele wychowania}

Omawiając terminologię związaną z wzorcami osobowymi w życiu każdego człowieka, należy również wspomnieć o czterech modelach wychowania współczesnego człowieka (Wojciechowska 2002). Pierwszy to model pozostawienia zupetnej swobo$d y$, który wskazuje, że rodzice powinni unikać jakiegokolwiek wpływu na naturalny i spontaniczny proces rozwoju dziecka. Ich jedyną rolę stanowi tworzenie neutralnej atmosfery, aby nie zakłócać ujawniania się naturalnych, wrodzonych możliwości dziecka. Konsekwencją stosowania tego modelu może być ukształtowanie się osobowości o nieograniczonej autonomii, niewrażliwej na potrzeby innych ludzi. Jednostki takie mają trudności z akceptacją obowiązujących reguł i standardów społecznych, które traktują jako ograniczające swobodę, kreatywność i prawo do nieskrępowanej samorealizacji.

Drugi to model lepienia z gliny, w którym naczelną zasadą jest stwierdzenie, że dziecko można dowolnie formować wedle z góry przyjętych założeń, co dokonuje się z wykorzystywaniem kar i nagród, dawaniem przykładu, kształtowaniem nawyków. W konsekwencji stosowania tego modelu kształtują się osoby niesamodzielne, podporządkowane innym, niepotrafiące wyrażać własnej opinii, mające trudności z samodzielnym podejmowaniem decyzji, nieumiejące działać w sytuacjach wymagających kreatywności.

Kolejny to model konfliktowy, zakładający, że dziecko od urodzenia jest aktywne. Relacje między rodzicami a dziećmi mają charakter konfliktowy, co wynika z przyjmowania odmiennych celów. Rodzic, jako osoba o większej władzy, rozwiązuje konflikty przez narzucanie własnej woli. Model ten łączy oba poprzednie, zaś charakteryzuje go zmienne przyzwalanie na swobodne działanie w pewnych sytuacjach (np. w zabawie), zaś ograniczenie owego przyzwolenia w innych. W rezultacie jego stosowania dziecko 
uczy się konieczności walki o własne prawa i niezależności, ale też kształtuje się jego przekonanie, że świat opiera się na rywalizacji, którą wygrywają silniejsi. Konsekwentne i stałe narzucanie dziecku własnej woli przez rodzica może spowodować ukształtowanie się postawy bierności, bezradności, braku wpływu na otaczającą rzeczywistość.

Ostatni to model wzajemności $i$ wspótdziatania. Zakłada równorzędne partnerstwo dziecka w interakcjach z rodzicami, co kształtuje przekonanie o równoważności i równowartościowości partnerów interakcji, a także uczy poszanowania dla siebie i innych ludzi.

Takie zróżnicowane podejście do wychowania młodego człowieka było zjawiskiem zawsze towarzyszącym człowiekowi na przestrzeni dziejów. Pedagogiczny problem polega więc nie na tym, jak ochronić człowieka, którego chcemy wychować, przed oddziaływaniem przeciwstawnych bodźców, ale jak go przygotować do samodzielnego dokonywania racjonalnych i trafnych wyborów. Trudno przecież wyobrazić sobie przejście przez życie bez doświadczenia uczuć takich jak frustracja czy gniew, nie stając się uczestnikiem konfliktów. Rozwiązanie tych dylematów wymaga odpowiedniego działania i współdziałania rodziców, wychowawców, instytucji, innych organizacji oraz proponowanych współcześnie wzorów osobowych mających wpływ na wychowanie i kształtowanie młodego pokolenia. Od sukcesu tych działań zależy przyszły kształt naszego społeczeństwa oraz to, w jakich warunkach żyć będą nasze dzieci.

\section{Podsumowanie i wnioski}

Obecność wzorów osobowych w życiu współczesnego dziecka jest znacząca, ponieważ umożliwia kształtowanie określonych postaw i przygotowanie młodego pokolenia do pełnienia różnorodnych ról społecznych. Stąd ich istnienie jest pomocne w oddziaływaniu szerokiej grupy wychowawców, rodziców, nauczycieli, czyli osób, które z racji funkcjonowania w rolach rodzinnych i zawodowych angażują się w proces socjalizacji i wychowania dzieci i młodzieży. Mogą one odwoływać się do różnych wzorów funkcjonujących w życiu społecznym, wykorzystując je w świadomej działalności wychowawczej, a także oddziałując nieświadomie siłą osobistego przykładu. Możliwe jest również odniesienie się także do abstraktu, czyli wzorca osobowego, będącego uogólnieniem pożądanych cech, na przykład dobrego ucznia, przyjaciela, syna czy córki, dobrego pracownika. Wzory osobowe są potrzebne także w okresie dorosłości. Osoby je posiadające łatwiej podejmują nowe role społeczne, korzystając między innymi ze sposobu funkcjonowania znanych sobie modeli, którymi są często rodzice.

Warunki współczesnego życia nie sprzyjają zarówno kształtowaniu się wzorców osobowych, jak i ich oddziaływaniu. Współczesny człowiek traktowany jest jako jednostka samowystarczalna i całkowicie niezależna. W związku z promowaniem wartości 
indywidualistycznych takich jak autonomia i poczucie wolności, następuje przenoszenie wzorów życia z krajów zachodnich, przy czym dominuje koncepcja wolności jako pełnej swobody, niezależności od innych osób, norm i zasad.

Niedobór pozytywnych wzorów osobowych w życiu społecznym, tendencja do deprecjonowania autorytetów sprzyja łatwemu uleganiu powierzchownym i niestabilnym wzorcom, często sztucznie kreowanym przez media i niesłużącym rozwojowi jednostki. Dynamiczny rozwój nowych technologii powoduje zwiększenie wpływu wzorów i wzorców za pośrednictwem mediów. Zakres oddziaływania środków masowego przekazu znacznie wzrasta, wypełniając nie tylko czas wolny dziecka, ale również czas zajęć szkolnych. Zwraca się uwagę, że lansowanie przez środki masowego przekazu postaci idoli i celebrytów jest formą kompensacji braku wartościowych wzorów osobowych w życiu społecznym. W złożonym układzie modeli kształtujących osobowość dziecka i nastolatka znajdują się również wzory niedostępne w bezpośrednich interakcjach, lansowane przez media (muzyk, aktor, sportowiec, modelka), oraz wzory będące postaciami fikcyjnymi (bohaterowie gier komputerowych, postaci z filmów). Szczególnie w okresie adolescencji ich oddziaływanie ma istotne znaczenie ze względu na silną potrzebę samookreślenia się młodego człowieka.

W świetle powyższych rozważań można sformułować wniosek, zgodnie z którym oddziaływanie wartościowych, dojrzałych wzorów osobowych, sprzyjających identyfikacji jednostki na rożnych etapach życia, stanowi niedoceniany współcześnie i mało świadomie wykorzystywany czynnik rozwoju. Ich brak zwłaszcza obecnie, w czasie dokonujących się procesów globalizacyjnych i mieszania się kultur, może być źródłem trudności w kształtowaniu się osobowości jednostki, jej tożsamości i powodem słabości współczesnego człowieka.

Biorąc pod uwagę rozważane kwestie dotyczące wzorców osobowych, należy podkreślić, iż są one bez wątpienia zbiorem cech, do których posiadania powinien dążýc każdy człowiek. Każdy z nas posiada własny system wartości oraz ideał postępowania, do którego zmierza. Ważną rolę w życiu każdego z nas, również współczesnych dzieci i młodzieży, odgrywa samodoskonalenie, które powinno być procesem, do którego dochodzimy poprzez próby i błędy popełniane w życiu. Tego również powinniśmy uczyć młode pokolenie od najmłodszych lat, aby prawidłowo funkcjonowało w realnym świecie. Wzorce osobowe, które znacząco zmieniały się poprzez wieki, nie zatraciły podstawowych wartości moralnych pozwalających normalnie żyć każdemu z nas. Takimi wartościami jest dobro, prawda czy miłość. Zatem za wzorce osobowe powinniśmy uważać ludzi kierujących się w życiu tymi właśnie wartościami. Nie muszą to być ludzie sławni, można ich znaleźć również pośród nas. 


\section{Bibliografia}

Badura E. (1981). Emocjonalne uwarunkowania autorytetu nauczyciela, Warszawa: Wydawnictwa Szkolne i Pedagogiczne.

Bakiera L., Harwas-Napierała B. (2016). Wzory osobowe w rozwoju cztowieka, Poznań: Wydawnictwo Naukowe UAM.

Bandura A. (1985). Model of causality in social learning theory, [w:] A. Freeman, M.J. Mahoney, P. Devito, D. Martin (red.), Cognition and psychotherapy, New York: Plenum.

Bąbel P., Suchowierska M., Ostaszewski P. (2014). Naśladowanie a uczenie się przez obserwację. Porównanie perspektywy analizy zachowania i teorii spotecznego uczenia się, „Psychologia Rozwojowa", 19(3), 37-47.

Bronfenbrenner U. (1970b). Czynniki spoteczne w rozwoju osobowości, przekł. A. Gołąb, „Psychologia Wychowawcza” 2, 141-161.

Dobrowolski S. (1948). Wychowanie i wychowawca. Rodzic-nauczyciel-mistrz, Warszawa: Instytut Wydawniczy „Nasza Księgarnia”.

Fudali M. (2008). Gimnazjaliści uczestnikami kultury mtodzieżowej, „Edukacja i Dialog” 10, http://www.eid.edu.pl [dostęp: 15.10.2015].

Gerstmann S. (1961). Autorytet wychowawcy, „Nowa Szkoła”, 12, 14-17.

Graczykowski P., Trojan K. (2003). Temperamenty, charaktery, osobowości: profil medyczny i psychologiczny, Kraków: Wydawnictwo „WAM”.

Harwas-Napierała B. (2010). Wzór osobowy ojca w rozwoju dziecka, [w:] M. Kujawska, L. Huber (red.), Postawy rodzicielskie wspótczesnych ojców, Poznań: Wydawnictwo Naukowe Wyższej Szkoły Nauk Humanistycznych i Dziennikarstwa.

Kopaliński W. (2007). Stownik wyrazów obcych i zwrotów obcojęzycznych z almanachem, Warszawa: Oficyna Wydawnicza RYTM.

Kumaniecki K. (1999). Stownik tacinsko-polski, Warszawa: Wydawnictwo Szkolne PWN.

Kwiatkowski A. B. (2013). Wzorce osobowe dziataczy spoteczno-politycznych, Pułtusk: Akademia Humanistyczna im. Aleksandra Gieysztora.

Kwieciński Z. (1996). Edukacja wobec wyzwań demokracji, [w:] H. Kwiatkowska, Z. Kwieciński (red.), Demokracja a oświata, ksztatcenie i wychowanie, Toruń: Polskie Towarzystwo Pedagogiczne, Edytor.

MacIntyre A. (1996). Dziedzictwo cnoty. Studium z teorii moralności, Warszawa: Wydawnictwo Naukowe PWN.

Masłyk-Zawisza E. (2013): Medialne zawtaszczanie wptywu spotecznego na życie nastolatków, [w:] J. Morbitzer, E. Musiał (red.), Człowiek-media-edukacja, Kraków: Katedra Technologii i Mediów Edukacyjnych. Uniwersytet Pedagogiczny.

Ossowska M. (1992). Wzór demokraty. Cnoty i wartości, Lublin: Instytut Wydawniczy Daimonion.

Plezia M. (red.). (1974). Stownik tacińsko-polski, Warszawa: Państwowe Wydawnictwo Naukowe.

Przetacznik-Gierowska M., Włodarski Z. (1994). Psychologia wychowawcza, T. 2, Warszawa: Wydawnictwo Naukowe PWN.

Siuta J. (red.). (2005). Stownik psychologii, Kraków: Wydawnictwo Zielona Sowa. 
Spychalska J. (2012). Idol w mediach jako czynnik ksztattujacy mtodzież, [w:] J. Aksman, J. Pułka (red.), Dzieci i mtodzież w kregu oddziatywania mediów i grup rówieśniczych w i pomimo czasów ponowoczesnych, Kraków: Krakowska Akademia im. Andrzeja Frycza Modrzewskiego.

Turner J. S., Helms D. B. (1999). Rozwój cztowieka, przekł. S. Lis, J. Mańk-Kowalska, A. Radomska, L. Wojciechowska, D. Zawadzka, W. Zagórska, Warszawa: Wydawnictwa Szkolne i Pedagogiczne.

Wojciechowska A. (2002). Cztery modele wychowania. Który wybrać? „Edukacja i Dialog” 12.

Netografia

https://encyklopedia.pwn.pl/haslo/wzor-osobowy;3999283.html [dostęp: 29.08.2021].

\section{ADRES DO KORESPONDENCJI}

Marta Kuźnik

Uniwersytet Śląski w Katowicach

e-mail:m-kuznik@wp.pl 